\title{
Waldeyer's Tonsillar Ring
}

National Cancer Institute

\section{Source}

National Cancer Institute. Waldeyer's Tonsillar Ring. NCI Thesaurus. Code C73468.

The ring of lymphoid tissue located in the pharynx, consisting of the pharyngeal, tubal, palatine, and lingual tonsils. 